\title{
A journey of negotiation and belonging: understanding students' transition to science and engineering in higher education
}

Holmegaard, Henriette Tolstrup; Madsen, Lene Møller; Ulriksen, Lars

Published in:

C S S E

DOI:

$10.1007 / \mathrm{s} 11422-013-9542-3$

Publication date:

2014

Document version

Publisher's PDF, also known as Version of record

Citation for published version (APA):

Holmegaard, H. T., Madsen, L. M., \& Ulriksen, L. (2014). A journey of negotiation and belonging: understanding students' transition to science and engineering in higher education. C S S E, 9, 755-786.

https://doi.org/10.1007/s11422-013-9542-3 


\title{
A journey of negotiation and belonging: understanding students' transitions to science and engineering in higher education
}

\author{
Henriette Tolstrup Holmegaard • Lene Møller Madsen • \\ Lars Ulriksen
}

Received: 10 April 2012/ Accepted: 23 August 2013

(C) Springer Science+Business Media Dordrecht 2013

\begin{abstract}
The paper presents results from a longitudinal study of students' decisions to enrol on a higher education science programme and their experiences of it. The aim is to give insights into students' transition process and negotiation of identity. This is done by following a cohort of 38 students in a series of qualitative interviews during a 3-year period starting as they were about to finish upper secondary school. We find that the students' choice of study is an ongoing process of meaning-making, which continues when the students enter higher education and continuously work on their identities to gain a sense of belonging to their science or engineering programme. The use of a narrative methodology provides understanding of choice of study as involving changes in future perspectives and in the interpretation of past experiences. Further, we gain access into how this meaningmaking process over time reflects the students' negotiations in terms of belonging to higher education and their coping strategies when their expectations of their new programme interact with their first-year experiences.
\end{abstract}

Keywords Transition to higher science education - Identities · Educational choice $\cdot$ Student narratives $\cdot$ Negotiation strategies

\section{Resumé}

Denne artikel handler om en gruppe af studerendes overgang fra udvalgte gymnasiale uddannelser til de længere videregående tekniske og naturvidenskabelige uddannelser. Ved gentagende narrative interviews med 20 studerende over en tre-årig periode, undersøges

Lead Editor: W. Pitts

H. T. Holmegaard $(\bowtie) \cdot$ L. M. Madsen · L. Ulriksen

Department of Science Education, University of Copenhagen, Øster Voldgade 3, 1350 København K, Denmark

e-mail: hh@ind.ku.dk 
interaktionen mellem de studerendes forventninger til uddannelsen og de erfaringer de studerende oplever i mødet med deres nye studie. Fokus er på, hvordan de studerende forhandler deres identiteter i transitionsprocessen i forsøget på at skabe et tilhørsforhold til deres nye uddannelse. Der udvikles en analytisk optik, der kobler narrativ psykologi med teorier om akademisk integration. Begrebet turning points oversættes til denne ramme, og benyttes til at identificere særlige forhandlinger i de studerendes narrativer. Vi får gennem den longitudinale metode adgang til at forstå denne proces over tid.

Analysen viser, hvordan de studerendes valg er en fortløbende proces, der fortsætter også efter, at de er startet på deres videregående uddannelse. Denne proces udfordres af, at alle studerende oplever en afgrund mellem deres forventninger til deres uddannelse og deres erfaring i mødet med den. En vigtig pointe er således, at samtlige studerende må forhandle deres forventninger til studiet, men også til deres forestilling om, hvem studiet vil give dem adgang til at blive. Afgrunden gør det således vanskeligt for de studerende at genkende det studie og indhold de egentlig har søgt ind på. De studerende søger at mindske afgrunden med forskellige forhandlings-strategier, der relaterer sig til størrelsen af afgrunden og deres fors $\emptyset \mathrm{g}$ på at tilpasse deres narrativ til de nye erfaringer gennem få justeringer eller løbende og intensive forhandlinger De studerendes forhandlinger relaterer sig primært til indholdet på de kurser de møder, de faglige krav, organiseringen af studiet samt undervisnings- og læringsaktiviteter. Nogle studerende fors øger at forhandle indholdet ved at engagere sig i aktiviteter uden for studiet, andre opgiver at skabe mening i det indhold de præsenteres for mens andre igen knokler for at finde mening i indholdet. Vi finder ingen sammenhæng mellem kvaliteten af de studerendes valgovervejelser - i hvilken udstrækning de har sat sig ind i deres nye uddannelse, og deres forhandlingsstrategi. Ligesom vi ikke ser en direkte sammenhæng mellem forhandlingsstrategi og frafald. Risiko for frafald afhænger dog blandt andet af, hvor meget de studerende skal forhandle og hvor stor afgrunden er. I alt identificeres fem forhandlings-strategier, der udfoldes i analysen.

Artiklen har betydning for flere niveauer. På et teoretisk niveau bringer den ny viden til sociokulturelle teorier om studerendes ujævne veje ind i Akademia. Særligt udvider den Tintos begreber om social og akademisk integration ved at vise, betydningen af mere end ét akademisk system. Derudover foreslår vi, at udvide Tintos model til at være mere sensitiv overfor forskellige studenter baggrunde ved at inkludere et blik for, hvordan identiteter skabes som løbende forhandlinger. Artiklen er samtidig relevant for undervisere, planlæggere og universitetsledelse, da den viser, hvordan mødet med universitetet er en skrøbelig proces, hvor selv studerende, der er overbeviste om, at netop de vil gennemføre, udfordres i at konstruere et gangbart narrativ og derfor udsættes for overvejelser om at forlade uddannelsen.

\section{Students' transition to higher education}

This paper investigates the transition processes that students go through when they are enrolled in higher education science and engineering programmes. Our methodological focus is on students' narratives. Therefore, we begin this paper by introducing Emil, one of the Danish students whose narratives form the basis of this paper. The first quote is from an interview with Emil shortly before he finished upper secondary school:

Researcher: What do you think it will be like [attending higher education]?

Emil: It's going to be hard, I guess. But I think... then again it won't, because I'm aiming for it to be something I find interesting, and then I could, like, study as if it was a hobby. When I'm at home I will be studying. That's what I hope at least, that it 
will be as interesting as I hope, that I'll just say - 'let me read this book', and it will be so interesting that I prefer that instead of watching television or something [...] Researcher: What do you think the study programme needs to be like for you to get to like it?

Emil: I am not sure, but I would like it to be social. And with a lot of theory combined with some practice [...] I thought of choosing biochemistry because I am interested in chemical processes in micro-organisms.

\section{(Emil in upper secondary school, April 2009)}

In an interview 5 months later, Emil was a few weeks into his first year of university biochemistry studies:

Emil: We will finally meet what they call biochemistry at the second year. So it is kind of... I did not know we were to have mathematics in this way [as the major course]. And it was a surprise to me. And there are also many of the other students who said that they would probably have chosen something else if they had been aware of it.

Researcher: Would you have chosen something else too?

Emil: No, I don't think so, now that I have settled for biochemistry. But I might have reconsidered engineering; if I began considering stuff like, what to use it for later on (...) I understand why somebody would want to study something else because first year is like 'you can continue if you manage to get through it'.

\section{(Emil, Biochemistry, September 2009)}

Emil experienced a gap between the expectations he had of his future study programme while at school and the actual experiences he had upon entering higher education. If Emil is to experience his study programme as meaningful, he will have to reconsider the reasons why he is studying biochemistry. In other words, Emil needs on the one hand to bridge the gap between his expectations of biochemistry being as interesting as a hobby, being about chemical processes and including practical work, and, on the other hand, his experience of biochemistry as being something quite different from that, namely as dominated by a course in mathematics that he finds it hard to relate to.

Our aim in this paper is to explore and understand this meeting of students' expectations of the higher education programmes by analysing their narratives about why they chose a particular programme, and how they relate these narratives to their actual first-year experiences. Our interest in this process is how students negotiate their identities and retell their expectations in a way that fits their understanding of what it takes to belong in their new study programmes. We study the transitions as processes between the two educational levels, and our aim is to focus on student integration, engagement and empowerment, rather than on retention and withdrawal. Hence, the approach of this paper differs from much of the previous research on students' transition from upper secondary school to higher education in two ways. First, by studying the transition as precisely that: a process of moving from one place to another; and, second, by looking at the role ascribed to identity in this process. At the same time, we contribute to a research approach that has emerged over the past decade.

Sara Goldrick-Rab, Debrorah Faye Carter and Rachelle WinkleWagner (2007) show that research on the transition to post-secondary education is dominated by two particular foci: college entry and college completion, themes that Peter Scott states relate to the economic interest of higher education institutions (1995). As such studies have primarily 
tended to focus on either the transition from or the transition to with a focus on either upper secondary school or higher education.

The research literature focusing on the transition from upper secondary school has been particularly influenced by studies from North American. In an extensive review of students' choices, Amy A. Bergerson (2009) shows how an economic interest is not the only reason for studying students' transition. Another is a concern for the social inclusion of students' different chances of accessing higher education. In particular how their financial, social and ethnic backgrounds influence their transition to higher education. Clifford Adelman (2006) found, for example, that in a US Department of Education report certain institutions, courses (in science/mathematics and languages) and students' course levels especially in mathematics turned out to be key predictors of higher education attendance. Patrick Terenzini, Alberto Cabrera and Elena Bernal's (2001) report is an example of how the whole of the transition process is included, by showing how poor students encounter higher education. In a British context, research in students' transition from upper secondary school has been dominated by studies focusing on their educational choices and preparedness for entering higher education. An example is a longitudinal study of students' pathways in London by Stephen Ball, Meg Maguire and Sheila Macrae (2000) who, similarly to Adelman (2006) in a US context, conclude that choices are not only influenced by class, ethnicity and gender but also by institutional cultures and expectations.

The research literature focusing on transition to higher education is to a large extent dominated by studies that address students' success and retention by mapping their preparation, interests, abilities, amount of work, etc. However, as we have shown in Lars Ulriksen, Lene Madsen and Henriette Holmegaard (2010) recent research has shifted the focus from perceiving success and retention as solely a question of students' adaptation to institutional requirements towards retention as a relation between the students and the culture of the programme they enter and also an increasing concern for issues of identity. We see the present paper as an empirical contribution to this shift towards identity.

Throughout the research literature there are calls for investigations that do not merely reduce the problem to one that is situated in either upper secondary or higher education:

Many researchers argue, therefore, that it is only possible to understand transition through a focus on agency and identity together with an account of how they are shaped, constrained and sometimes determined by the material conditions and normative expectations of different structural factors. (Ecclestone, Biesta and Hughes 2010, p. 12)

Thus, to understand transition we must gain knowledge of how people work on their identities in the process of moving from one cultural context to another. Kathryn Ecclestone, Gert Biesta and Martin Hughes (2010) suggest that focus should be on the identity process, the process of becoming somebody, across institutional and cultural contexts.

This is mainly a theoretical statement; and it is supported by a large review of existing research-primarily from the UK-performed by Mantz Yorke and Bernard Longden (2004) who are concerned with the large number of students who drop out from their courses. Leaving higher education is a process which takes place over time, and the authors conclude that the following reasons are crucial in terms of staying and leaving: students' reasons for entering the programme in the first place, their experiences of the programme, their coping strategies in the face of difficulties, and finally factors outside the institutions (Yorke and Longden 2004). 
Against this background, the aim of this paper is to understand transition to higher education first as a process from one educational level to another educational level. Second, transition is understood not just as transition to a new institutional context, but also as a transformation of students' expectations and identities. In other words, this paper explores the transition processes through which students learn to become students within higher education in science, technology, engineering and mathematics (STEM).

\section{Research framework; combining identities in transition and academic integration}

To understand students' transition to their first year in higher education science and engineering programmes we combine ideas from various socio-cultural approaches to extract the theoretical concepts with which to approach analysis. By socio-cultural, in line with James Wertsch (1993), we mean a range of theories with an interest in the reciprocity and constitutive processes of subjects and culture(s). In this paper we wish to understand the aspects of socio-cultural thinking at two particular focal points in the process of students' moving from upper secondary school to higher education: identities in transition and integration into academia. We unfold the concepts by drawing on narrative psychology and post-structuralist thinking. In this section we present our research framework, and describe how it will enable us to approach our research aim.

\section{Identities in transition}

Transition is more than a linear process of moving from one institutional context to another in which the student needs to make sense of a new social and cultural arena. Ecclestone, Biesta and Hughes (2010) underline that transitions are processes in which students work on their identities to become 'somebody', to fit into what they recognise as institutional and culturally accepted pathways and reach a sense of belonging. In this perspective identities are perceived as fluently and dynamically constructed through the discourses available in the cultural setting. Identities are always in transition. This post-structuralist approach to identities as constantly negotiated allows us to perceive students' meeting with their new study programme as a continuous process in which they continue to work at making meaning of and relating to the new cultural setting.

In narrative psychology meaning-making processes are perceived as culturally embedded in the sense that the students draw on cultural storylines when they construct their narratives. Jerome Bruner describes these ways of making meaning as culturally shared in the sense that 'we live publicly by public meanings and by shared procedures of interpretation and negotiation' (1990, p. 13). Also Donald Polkinghorne (1988) highlights how-through culturally embedded narrative configurations - we understand our existence as an expression of a single progressive story and achieve a sense of self and identity. One of these culturally shared storylines is how identity is seen as a core of self carried within each of us. Therefore individuals perceive themselves as possessing a coherent self. Fitting into a new cultural setting such as higher education is therefore also a process in which students need to construct new coherent narratives about how they belong in this particular study programme and how it fits with their perceptions of themselves. As Wolff-Michael Roth and Kenneth Tobin explain, 'events in our lives may provide us with resources to understand ourselves differently, leading to changes in our biography' (2007, p. 1). In the same vein transition to higher education also makes new narratives possible through the cultural resources available in the given study programme. 
According to Bruner (1990) our narratives do not appear reliable and valid if they are too flexible. This does not mean that we do not change. Polkinghorne (1988) explains how we reverse the plot in our narratives as new events occur and new perspectives on how these events will end and who we will become emerges. The point is, however, that we need to align the new perspectives in our lives with our sense of self.

So how on the one hand can we state that identities should be relatively stable to be culturally recognised and on the other hand perceive identities as dynamic and continuously in transition? We are interested in how this dilemma works out in students' transition to higher education.

We understand that the new student needs to work on becoming a recognised student to feel s/he belongs to and is recognised in the cultural context of her/his new study programme. In this process s/he will have to negotiate her/his expectations of what studying will be like, and work on her/his identities to gain a sense of belonging. On the other hand, s/he needs to be recognised as her/himself, and therefore s/he cannot construct new narratives without somehow being related to the person s/he perceives her/himself as being and how her/his surrounding social peers perceive her/him.

As unfolded by Holmegaard and her colleagues (Holmegaard, Madsen and Ulriksen 2012) there might be a mismatch between how students perceive themselves and their expectations of who to become in their study programme, the perceptions and expectations of family and friends and finally the expectations and the pathways available in the programmes. From this perspective, Helen Colley (2010) argues that the process in which the students work on their identities (so as to belong to their new study programme and retain a sense of self) is a learning process in which they learn who to become and where to locate and position themselves in the new study programme. In this paper we are interested in this learning process.

\section{Integration into academia}

To understand how the above-described learning process takes place, and how students follow different pathways through it, Vincent Tinto (1993) used the notion of integration in his longitudinal model of students leaving college. A key component in the model was the process of integration in both social and academic communities. These communities are closely interwoven and they can consist of various subcultures. Further, the integration could both be formal and informal, occurring in the teaching settings, in social activities organised by the institution or in informal interaction outside class-with fellow students, with staff or with both.

Tinto's model has been criticised by for example William Tierney (1999) for being insensitive to the particular difficulties that non-traditional students experience when entering a culture dominated by white, male, middle-class or upper-class norms and codes. Tinto's model of student departure presupposed that minority students would commit cultural suicide by adopting the majority culture. Although we do not agree that this is necessarily implied by the model, we find that the critiques stress the importance of linking the model to how students negotiate their identities in various ways in the various academic cultures. Therefore we first need to unfold the notion of culture in order to use Tinto's notion of integration in our research framework. As noted by Dorothy Holland, William Lachicotte Jr., Debra Skinner and Carole Cain (1998) there is a tendency to treat cultural discourses and practices of a group of people as: 
(...) indicative of one underlying logic or essence equally compelling to all members of the group. Instead, contest, struggle, and power have been brought to the foreground. The objects of cultural study are now particular, circumscribed, historically, and socially situated 'texts' or 'forms' and the processes through which they are negotiated, resisted, institutionalized, and internalized. As Foucault insisted, significantly for the study of culture and self, 'cultural forms' are presumed to affect and shape subjectivity, and these cultural forms come in great variety. (Holland et al. 1998, p. 26)

We understand identities and students' narratives as always embedded in culture. Culture can be understood as a range of social practices one has to learn to become recognised within, as described by Cathrine Hasse $(2002,2008)$ in her study of first-year physics students. Another approach to culture is analytic, like Dorte Marie Søndergaard is in her study of gendered positions in academia (1996). Rather than social practice, Søndergaard focuses on discursive practices, and on how the culture sets the scene for students' gendered positioning of themselves and each other. In this study narrative interviews are conducted and we do not claim to gain access to the students' social practices, which is why our approach is in line with that of Søndergaard. Also we find ourselves in agreement with Karen Tonso, who understands the process of belonging as:

(...) a process through which persons' sense of themselves as engineers led to performances of engineer selves that were viewed through lenses of cultural forms for campus engineer identity, and where recognition as an engineer conferred belonging. (2006, p. 303)

We perceive the social and academic integration suggested by Tinto as students' strategies for gaining a sense of belonging. By combining Tinto's model with a sociocultural identity perspective we develop a concept for understanding students' negotiations of their identities.

Against this background of theoretical perspectives, we can split our research aim into following research questions:

1. We wish to explore how students work on their identities and produce narratives across the transition from upper secondary school to higher education science and engineering study programmes.

2. In particular we seek to describe in detail the negotiation strategies in their narratives on choosing a particular study programme and subsequent narratives after entry on why they have enrolled in a particular study programme.

3. We wish to understand what students perceive as legitimate integration strategies for becoming a recognised student within science and engineering in higher education.

\section{Framing the study and constructing the analytic framework}

\section{Background and the Danish context of the study}

The students in this study are followed in their transition process from Danish upper secondary school to STEM higher education study programmes. Here we provide a brief contextual background to support the reader in interpretation of the student narratives presented in the results section. 
Two significant conditions set the scene for higher education institutions in Denmark; all study programmes are free of fees and all students get government funding every month (about \$1,000). The EU-funded project IRIS (Henriksen, Dillon and Ryder expected 2013), found that these two conditions might explain why Scandinavian students in particular require their higher education programme to make personal sense to them. A similar point is made by Illeris and his colleagues who in a Danish context point out how choice of study is not only a question about what to study but also who to become and is as such strongly related to students' identities (Illeris, Katznelson, Simonsen and Ulriksen 2002). Further, a study by the present authors (Holmegaard, Ulriksen and Madsen 2012) shows that Danish students' choice of study is not only based on what they find interesting, but the interest is adjusted to whether, for example, the students find the study culture or their future career prospects attractive.

Owing to the government funding and no-fee-politic, students are in principle free of any economic constraints. An access to certain higher education study programmes however is regulated by requirements that students take certain subjects at specific levels during upper secondary school and obtain specific marks.

In particular, mathematics is required for certain higher education study programmes in social and natural sciences, law and humanities, one reason why this is a popular subject in upper secondary school (The Danish Ministry of Children and Education 2011).

A final issue worth mentioning is that most Danish STEM programmes are monodisciplinary; if a student chooses to study computer science, what $\mathrm{s} /$ he gets is courses related to computer science. During the first couple of years most courses are mandatory. Until recently most higher education students went from their bachelor programme to an extended master's programme within the same discipline. This is still in some programmes embedded in the culture as the right thing to do, despite the Bologna declaration which allows students to combine their bachelor programme with a range of different master's programmes (EU 1999). Once a programme is chosen it is rather difficult to change to other programmes during the bachelor's or master's study and there is only limited opportunity to combine different study programmes. Changing between study programmes is considered a drop out both by the institution and by the student.

\section{Selection of schools}

In Denmark, there are four types of upper-secondary schools giving equal possibilities for entering the higher education system (HTX, HHX, HF and STX). STX is a non-vocational general type of upper-secondary school with science as one of several tracks, whereas HTX consists of various tracks all specialized in science and technology offering a strong focus on application. According to the Ministry of Education and Ministry of Finance (The Danish Ministry of Children and Education and Ministry of Finance 2007) STX is the largest school, recruiting $66 \%$ of the upper secondary school students. HTX hosts $9 \%$ of the students.

Twenty-five per cent of the students in STX and thirty-four per cent from HTX are enrolled in classes specialised in mathematics and chemistry or physics. The number is even higher if high-level biology is included (The Danish Ministry of Children and Education 2010). In 2009, $61 \%$ of the students in STX were females but only $19 \%$ were females in HTX. $55 \%$ of the STX students' parents had a higher education background, the same number was $38 \%$ for the students in HTX (Table 2 in Ulriksen, Murning and Ebbensgaard 2009). 
In the present study six schools were chosen: four STX and two HTX upper secondary school classes. All schools were located in the eastern part of Denmark near Copenhagen (Zealand) making it easier to access the students. Two schools were located in the urban Copenhagen area, two in suburban Copenhagen and two in provincial towns. The schools were picked to reflect variations in the student population: (1) one STX school had a particularly large number of students with various minority ethnic backgrounds; (2) one STX school recruited students primarily from socially privileged geographical areas; (3) one STX school recruited students from both socially privileged areas and areas of social housing; (4) one STX school recruited students from both urban and rural areas; (5) one HTX school recruited students from a large city area; (6) another HTX school recruited students from a rural area and some students travelled up to one hour to get to the school.

All schools were selected on the basis of information from the Science Faculty at the University of Copenhagen, since a particular high number of their students enroll. The classes were picked to reflect various STEM-tracks; one specialised in science, mathematics and technology, one in chemistry, biology and technology and four in science and mathematics.

At each school the head teacher arranged a time for each class to complete questionnaires in school time. As described by Steinar Kvale (1996), this is not an unusual way of accessing data in a Scandinavian context where gatekeepers' permissions to access interview participants is regarded as ethically responsible if the participants themselves agree. The empirical set-up was approved by the Danish Data Protection Agency.

\section{Selection of participants}

In the six selected upper secondary classes, 134 students completed a questionnaire concerning their socio-economic background, interests in and experiences at upper secondary school, particularly regarding science and their plans for the future. On the basis of the information in the questionnaire we invited two students from each class to join a focus group interview. Furthermore, each of these students were encouraged to bring with them a friend from their class to make the setting as safe as possible and to make the students feel comfortable sharing their views in a group. Not all students succeeded in bringing a friend, but, in total, 19 students were interviewed in groups. Furthermore three students from each class were selected for in-depth interviews. In one class, an extra student was interviewed because only two students showed up for the focus group interview. In total 38 students were selected for interviews; 19 students were interviewed individually and 19 in focus groups.

Seven of the students who were interviewed came from homes where a language other than Danish was spoken, 18 of the students came from families with non-academic backgrounds and 19 of the students were male and 19 female. We did not select the students to reflect the general population of students in upper secondary school. Rather, our selection criterion was to reflect various student narratives as to represent a maximum variation case as described by Bent Flyvbjerg (2011). This was done with the purpose of capturing a range of ways in which a diverse group of students approach their transition into higher education. In that respect, we strove to identify an array of possible strategies. We do not claim that the results are generalisable to all students in Denmark nor that we mapped all possible outcomes.

Of the 38 students, 25 entered a science or engineering programme within the first two years after they left upper secondary school. All of these are shown in Table 1. Of the 
25 students, we managed to keep in contact with 20 between spring 2009 and autumn 2011 . In this paper we analyse their choice-narratives (indicated in Table 1).

In this paper quotations from the student interviews are followed by letters in parentheses that indicate when the interviews were conducted. The abbreviation 'us' means upper secondary school; ' $\mathrm{g} 1$ ' means the first gap year; ' $\mathrm{h} 1$ ' means first year in higher education; ' $h 2$ ' means second year. If the students were interviewed more than once during a given period, interviews are numbered by letters, e.g. ' $h 1 \mathrm{a}$ ' being the first and ' $h 1 \mathrm{~b}$ ' being the second interview during the first year in higher education.

All students individually volunteered to participate in the interviews. The duration of the interviews varied from 45 minutes to 2 hours. All interviews were recorded and transcribed verbatim. To conceal the identities of the students we have used pseudonyms and the actual names of their schools and later their universities are left out. Further, we have left out information about participants' narratives which could identify them.

\section{Narrative interviews}

Both the focus groups and the individual interviews were conducted as narrative qualitative interviews. In order to access the students' meaning-making and identity construction the narrative interviewing encouraged stories and descriptions in accordance with Molly Andrews, Corinne Squire and Maria Tamboukou (2008). The interviewer positions the student as the expert on her/his life, and asks questions about the narratives and notions the interviewee presents. In this way, the narrative is point of departure for the interview and focus is on how the student makes and ascribes meaning, as highlighted by Dorte Marie Søndergaard (1996). Therefore the researcher asks 'How?' and 'What do you mean when say thus...?', emphasising descriptions rather than engaging in a dialogue. The researcher pays attention to how s/he positions and recognises the student during the interview as a co-constructer of the narrative. This means that the interviewer is a co-constructor of the narrative, since her/his presence and the entire set-up are an unusual setting with asymmetric power relations as pointed out by Steiner Kvale (2006). By reflecting upon these issues, the researcher can be aware of her/his own position, and thus widen the responses by recognising and encouraging the students' narrative.

The number of interviews with each student is indicated in Table 1. Each interview lasted between 1 and 2 hours. The narrative psychological approach was combined with a semi-structured interview guide as described by Kvale (1996). In upper secondary school, the interviews concentrated on the following two pivotal themes: upper secondary school experiences in general and of science in particular, and on the students' considerations about their future. Under each theme some sub-questions were listed. Some were introduced during the interviews (e.g. 'Please describe your experiences with science during upper secondary school' or 'Will you please tell me about your considerations about the future?'). The students themselves addressed other issues in the interview; for example, job opportunities. When students were interviewed during their gap year(s) and during their first year of the programme a narrative approach was adopted. Each interview began with 'Please tell me what has happened since we met last time'. This was followed by questions about the student's narrative: e.g. 'Please explain how you experienced your first weeks of studying chemistry' or 'You said starting mathematics was a bit weird, what do you mean by weird?' 


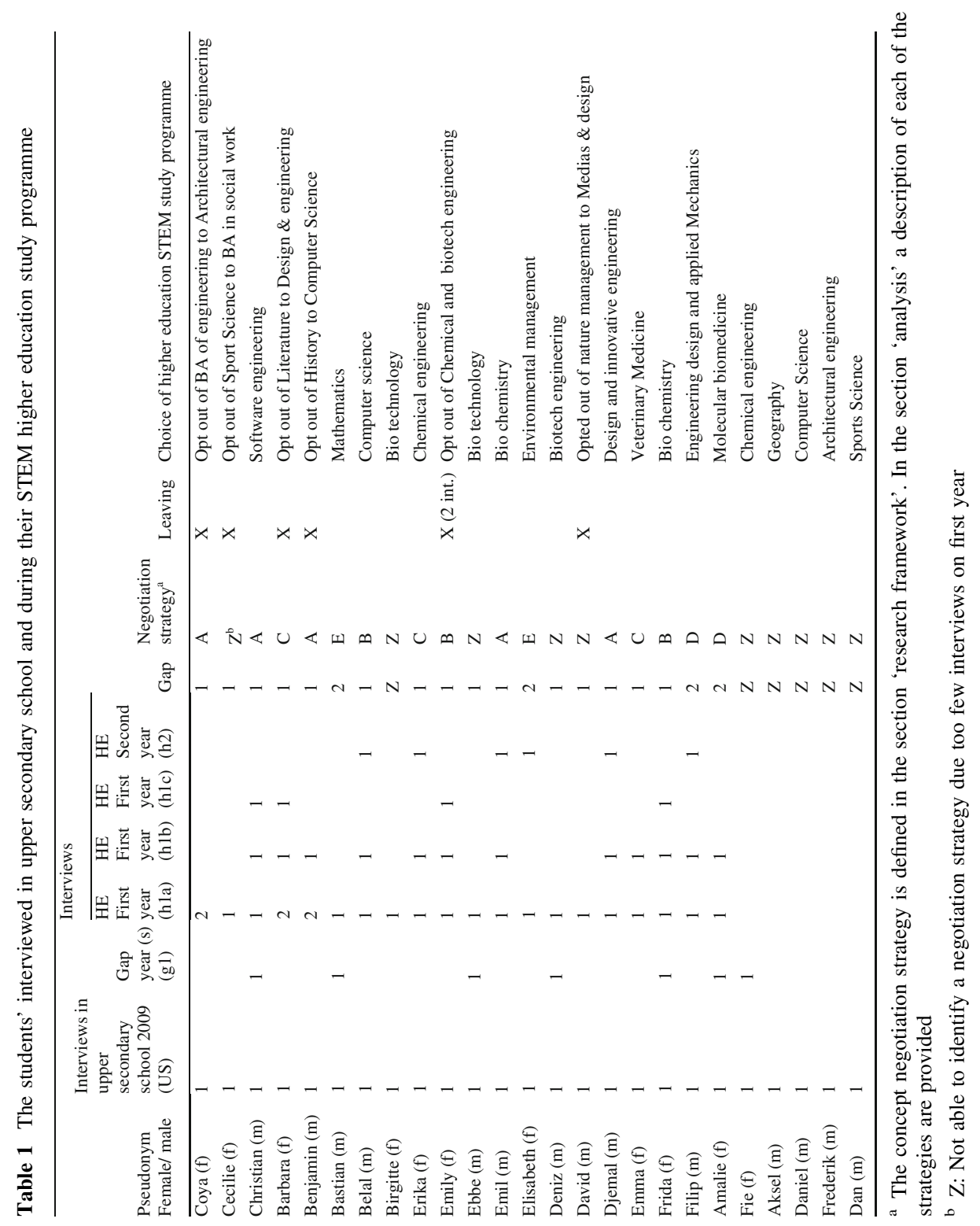


Analytic approach

All interviews were approached with the following analytical questions:

1. How do the students' narratives, about what they thought higher education science and engineering study programmes would be like, correspond to their actual experiences when meeting the study programme?

2. Which negotiation strategies do students use to transform their narratives into what they recognise as a legitimate way of belonging to their study programme?

To address the first analytical question, all interviews conducted with a particular student were read through one by one by the first author of this paper. Depending on their narratives and expectations in upper secondary school and their narratives when entering higher education, the students were categorised in two groups; the ones who encountered a big gap and the ones that encountered a small. The students were categorised in terms of how much they needed to struggle and negotiate their narratives and sense of self to match their new study programme and gain a sense of belonging. More precisely their narratives and expectations of higher education while in upper secondary school were compared with their narratives about their actual experiences when they entered higher education. Within each of the two categories, the students were further categorised in terms of the nature of the aforementioned gap; for example, did they struggle with unexpected content, study culture or motivation? This was done in accordance with Virginia Braun and Victoria Clarkes' thematic analysis (2006). Our analysis is organised according to these themes. The second and third author validated the analytic categories by reading selected interviews, and by discussing the categorisation.

In presenting the analysis, we selected students representing the maximum variation in the data to show the differences in their transition processes and to unfold the analytical process for the reader. A summary of the selected students' narratives will be presented in the analysis to ensure transparency. Approaching the second analytic question, we categorised the students in terms of what we label their negotiation strategies across the first year of higher education science and engineering. By negotiation strategy we mean the ways in which students adjust their identities to gain a sense of belonging through what they recognise as institutionally and culturally accepted pathways. To approach these negotiation strategies, we used 'turning points' as an analytic tool.

\section{Turning points as an analytic tool}

From a personality and developmental narrative psychological perspective it is studied how storytelling consists of sequences produced by turning points. Dan MacAdams, Ruthellen Josselson and Amia Lieblich (2001) describe how a sequence can turn from emotionally bad to emotionally good (redemption) or the other way round (contamination). Corinne Squire (in Andrews et al. 2008, Chapter 2) observes that a turning point is a significant event that sets the scene for retelling the entire narrative; e.g. 'When I did not pass my exams'. From a poststructuralist viewpoint these turning points are constantly taking place as the students constantly work on and negotiate their identities and their strategies for belonging. As stated in our research framework, however, identities are not totally re-negotiated all the time, and through narrative psychology we perceive some stability embedded in our cultural perceptions of selves. Therefore we understand turning points as sequences in students' narratives that indicate a change of perspective in terms of their consideration of the past and their expectations of the future. As suggested by Bruner (2004), the narratives are retold as new resources become available. By way of illustrating this concept of identity, imagine a car 


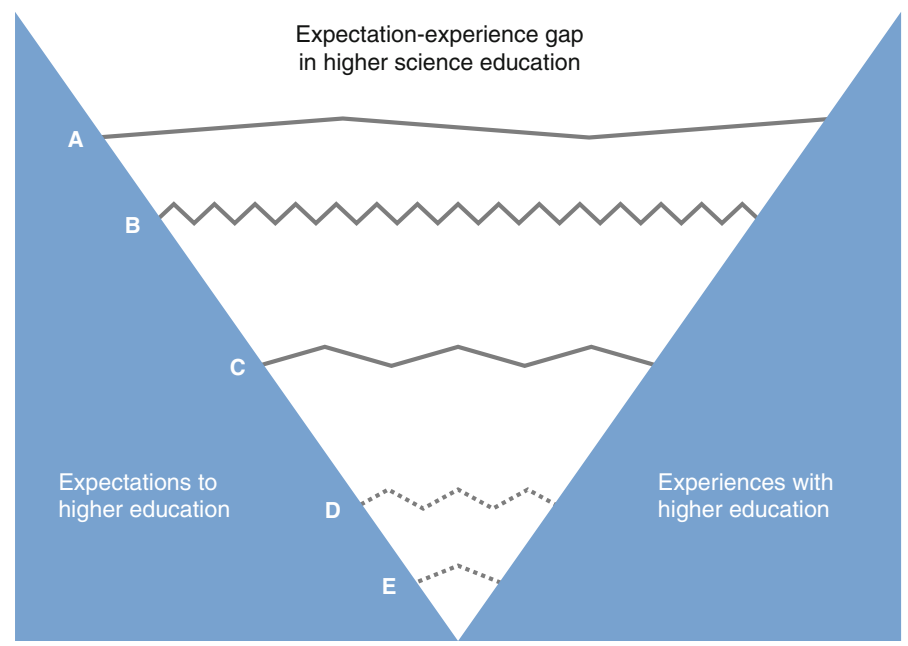

Fig. 1 Students' negotiation strategies in their transition to higher education. a Coya, Christian, Benjamin, Emil, Djemal, b Belal, Emily, Frida, c Barbara, Erika, Emma, d Filip, Amalie, e Bastian, Elisabeth

driving down a winding road. As the road turns, new images and landscapes become visible through the windscreen, but additionally the road behind the car appears at a different angle through the rear-view mirror. The same happens as students move through time. As they enter their new study programme, getting new friends and new perspectives on the world, they access resources which let them understand themselves differently both prospectively and retrospectively. In this paper we are interested in these turns in the road, and how students reconstruct their identities throughout their transition through higher education.

First of all, our analytical approach to the second analytic question is to identify sequences of turning points in the students' narratives over time. These are coded into five negotiation strategies (for an overview see Table 1 and for an illustration see Fig. 1). Second, we use our theoretical framework to relate these negotiation strategies to the students' identity work and integration strategies for becoming a recognised student within higher education science and engineering study programmes. To ensure transparency, this part of the analysis is presented by providing summaries of the students' narratives.

\section{Findings of students transition to higher education science and engineering}

This section is divided into two parts. The first part presents how the students' narratives about what to study in upper secondary school relates to their narratives when they enter their higher education study programme. The second part of the section is devoted to understanding the students' strategies when they encounter a gap between their narratives and what they meet when they enter their first-year higher education programme. In the latter part we wish to understand the students' negation and integration strategies when working on their identities in the process of bridging such a gap and gaining a sense of belonging to their study programme.

In the presentations of the results we use the conventional past tense. Occasionally, however, when presenting the concerns and dilemmas of the interviewees we use the present tense to emphasise the students' processes of reflection. 
Part 1: Expectations versus experiences

A majority of the students experienced a gap between what they had expected and what they experienced. The gaps frequently relate to the content, meaning, academic level of the courses or the teaching methods used, but some also experience gaps in relation to external factors (e.g. transport, housing, economic challenges). In the following, we first present students who clearly experienced a gap, followed by a section about students where the gap was less pronounced.

\section{Group 1: Students who encounter a gap}

The two citations from the interviews with Emil in the introduction to this article leave no doubt that he was surprised by the content of the study. The study programme contained far more mathematics than he expected, and he struggled to see how it related to biochemistry at all. Biochemistry, he explained, would not be part of the curriculum before the second year, and the lab coats all students had received during the first week, still lay unused in the students' lockers because they had not been to the laboratory. Emil concluded that the first year was something he needed to get through.

This acceptance clashed with another expectation, namely what he experienced studying to be like: a hobby and driven by interest. Rather, Emil struggled to keep up his motivation, and after a few months he reflected whether he would have 'reconsidered engineering if I began considering stuff like, what to use it for later on' (h1a). At the same time, he had a strong determination to complete the bachelor's programme because he would consider it a waste of time to leave and begin a new study programme, e.g. engineering.

Emil experienced a gap in at least two areas: the content and the motivation. A third point - that the future perspective might not be so attractive - appeared to be something he had not considered previously but that occurred to him after he had entered university. However way, his expectations had not been met.

Other students had similar experiences—both concerning experiencing a gap and this being related to the content. An example was the male student, Djemal, who entered an engineering programme in design and innovation and was surprised by 'a lot of courses where we need to draw, I did not expect that at all and it came as a surprise to me' (h1a). Djemal found it hard to see himself in the programme: 'it does not suit me' (h1a). He experienced difficulties with the course he liked (the science course), but was doing well in the more social science-oriented courses that he did not like in particular. During the first semester he considered leaving the programme, but since 'it takes five years, no less' he decided to stay, and further said that 'I am sticking to this study programme because I know what I want to do when I finish it' (h1b).

In upper secondary school Djemal had considered applying for physics and engineering to combine his interests in astronomy with a realistic career prospect, but also because engineering was a legitimate choice of study in the eyes of his family. Just before sending the application he changed his mind, and opted for design and innovation because of his interest in mobile phones, hoping to become a phone designer. In the design programme, however, students were not allowed to work with mobile phones in assignments at all.

For other students, the gap did not relate to the content, but to the difficulty of the courses. David opted for nature management, and had a clear idea of which courses he would have to do, and how many hours of teaching a week he would have. In the study programme he struggled with what he described as the level of the courses: 
Mathematics is at a really high level, and I think everybody finds it difficult and dreads the exam (...). When I am sitting at a lecture and think: 'I never heard about this before', and he [the teacher] says 'this is something you ought to know from upper secondary school' (...) and everybody is nodding, then it can be hard to get going, because it is additional stuff and I do not even know the fundamentals. (David, h1a)

David's experience is ambiguous. On the one hand, he articulates that everybody has difficulties in mathematics, but, on the other hand, how everybody except David has the prior knowledge from upper secondary school to understand the content. In any event, the experience appears to weaken his motivation.

At the same time he found it difficult to organise his study practice, because he found it hard to find out on his own what was important and what was less important. The need to organise the study practice, however, also related to the university programme not being his sole interest. He explained that to continue being motivated in his new study programme he needed to 'learn to study the right way, so I get most possible time alongside studying, so I do not have to use all my time on it, and don't feel it is so hard' (h1a).

The experience of a gap between academic preparation and the requirements of the programme was shared by many students in our study. For David, however, this experience was interwoven with other elements such as study strategies and teaching methods.

For one of the interviewed students the challenge of entering university was not related to the content but to the economic resources required-even in a tuition-free educational system. Emma had a disadvantaged background and was already living alone, taking care of her herself, while in upper secondary school. Through a determined effort she managed to gain a place on the veterinary science course, a highly selective programme.

In the interview just after she had started studying she told that she was worried because the books were much more expensive than she could possibly afford and she needed to move to a cheaper room to be able to continue studying. Finding a cheaper room had taken some time and effort and she said she was lucky that her first course in chemistry was one of her A-level subjects from upper secondary school, so she could keep up without spending a lot of time on it. On the other hand, she had not yet had the time to participate in the social part of the study life, which she hoped she could do now she had found a new room.

Group 2: Students who encounter less of a gap

A second group of students only experienced a slight gap when starting the first year of higher education. Of the 20 interviewed students, four were coded as belonging to this group. One of these students was Amalie, who said that molecular biomedicine was an obvious choice for her. Her parents studied biochemistry and molecular biology and two of her grandparents were engineers and one worked in biochemistry. In upper secondary school Amalie said she considered studying molecular biomedicine because it offered a way into research on the body, health and disease, without including clinical medicine. During her gap year, Amalie visited the molecular biomedicine programme at the university and in the interview during her gap year she said the study programme was very research-oriented and her description of the courses she would take during the first year, the content, the teaching and the organisation of the study, were concrete and seemed accurate. That level of accuracy was unusual in the students' narratives. 
When Amalie was interviewed again after entering molecular biomedicine she found the academic requirements in organic and inorganic chemistry to be suitable. During most of the interview Amalie talked about the social environment and the culture of the study programme which really fascinated her. She explained that she spent a lot of time with her fellow students, something she perceived as an investment:

The more you feel committed to your studies, the more you feel like you want to stay and make an effort. People who doesn't really do this, have been sitting kind of alone or maybe considered, not actually dropping out, but thought that it was boring. When that's how you feel, it's the social side that helps you keep committed. (Amalie, h1a)

When asked whether the study programme had met her expectations, she explained that she was pleasantly surprised by the social part of the study programme and had become much more involved than she had expected.

Concerning the academic content she said that she 'did not expect to find anything interesting during the first year where everybody needs to get to the same level' (h1a). Amalie's expectations in this respect were apparently formulated in retrospect rather than in advance. At least, she had not mentioned during the interviews in upper secondary school and during her gap year that she expected the first year not to be interesting. Hence, it is difficult to say whether Amalie only encountered a small gap between her expectations and actual experiences because of the clear match between expectations and experiences (and in the interviews she did not mention that she expected the first year to be boring) or if it was a result of a successful renegotiation of her expectation. In any case, Amalie was content and believed the course was what she expected.

Bastian and Elisabeth also had clear ideas about the studies they were to undertake, and experienced an alignment between expectations and experiences. During upper secondary school Bastian had been involved in a youth science association organising extra-curricular science-related activities (seminars, camps, etc.). Through this, he had met students at the university and heard their perceptions and descriptions of what university mathematics was like before he decided to enter the maths programme. Elisabeth had very carefully read through a lot of material, talked with career advisers and spoke to the staff of the course to ensure that she made the right choice. Her expectations and what she experienced at university matched fairly well. The only thing that surprised her was the level of the mathematics: 'It goes much faster than I have been used to. But I am happy, because I was often bored at upper secondary school, where it went a bit slow-so this pace suits me fine' (h1a).

Both Bastian and Elisabeth had moved to a university in a different part of the country, leaving their friends and families behind. Elisabeth had decided on a programme that was only offered at a particular university and therefore had to move. She felt settled in the new city, and experienced an inclusive social life in the rather cosy course (fewer than 20 students started together with her). Elisabeth was satisfied with the content, the level, the social life, the career prospects, and the housing.

Bastian deliberately chose a university away from home in order to try something new, but was surprised at how hard it was to find accommodation close to campus. Eventually, he had to settle some distance from the campus which hampered his participation in the social life at university because the last bus to his hall of residence left early in the evening. Moving to a new city made him feel a bit lonely sometimes, but academically his only surprise was how easy the weekly assignments were. Therefore, when asked to rate his feelings about the study on a scale from zero to 10 (10 being 'very enthusiastic'), he rated the study programme at 10 , but the social experience between two and three, because it had 
been hard moving to the city and he had not made any new friends yet. The interviewer asked if this took up much of his energy, and he replied that it did: 'It's almost more important than doing well in the courses. Because, if I don't feel comfortable then I don't think I can complete it [the study]' (hla).

\section{Summing up part 1}

The majority of the 20 students interviewed in both upper secondary school and during their first year at university experienced a gap between what they expected and what they experienced. The gaps mainly related to the content and the academic level of the programmes in terms of the students' motivation and the experience of what it was like to be a student. For some, however, the conditions outside the courses proved more challenging than expected.

Thus, the gap-experiences of the interviewed students are very similar to those listed by Yorke and Longden (2004) as factors frequently mentioned as influencing non-completion: the decision-making (some of the students in our study made quite sudden decisions about what to study), the academic requirements, experiences with the programme and institution, and events outside the study (e.g. financial issues). We also find that several of these factors sometimes affect the individual student, and that they interrelate. This point is also emphasised by Tinto (1993).

The students experience difficulties with academic integration (Tinto 1993), both in meeting the requirements (and hence being acknowledged by the formal system) and in experiencing the programme content as relevant and interesting (hence questioning whether the programme is right for them). The experiences of the students suggest that difficulties with one side of academic integration could lead to difficulties with the other: disappointing content could weaken motivation and mean less effort, which could cause under-achievement. Some students also experience difficulties with social integration, whereas for others (e.g. Amalie) it is a way of getting through the challenging or disappointing academic experience. Similarly, Bastian's emphasis on the importance of improving social life is related to the importance of social integration in terms of staying in the programme.

This leads us to two points. First our analysis shows, that the gap-experience appears to be the rule rather than the exception. Higher education institutions should consider how to deal with this gap. Second, what may appear as insufficient engagement or lack of motivation or poor preparation could be a consequence of disappointing experiences with the programme, as also carefully unfolded by Bjørn Johannsen, Camilla Rump and Cedric Linder (Johannsen, Rump and Linder 2013). The relation between expectations and experiences is a dynamic and a multidimensional one and should be considered as such.

The focus of the following section is on how the students' experiences are related, how they cope with them, and with what results.

Part 2: Negotiation strategies to bridge the gap between expectations and experiences

The first part of the findings showed that all the students in this study, in varying degrees, experienced a gap between their upper secondary school narrative and their actual experiences of higher education science and engineering. In this second part of the findings we will explore how, when meeting a gap, students use various negotiation strategies in order to become integrated and follow institutionally and culturally accepted pathways to reach a sense of belonging. 
We divide this second part of the findings into three sub-sections, each presenting five different negotiation strategies. The five different strategies as illustrated in Fig. 1 are:

1. Students who encounter a small gap, using few adjustments to align their identities and narratives with their experiences in the first year. These are the four students from group 2 in the first part of the findings, and they use negotiation strategies D or E.

2. Students who encounter a big gap, using few adjustments to align their identities and narratives with their experiences in the first year. These students apply negotiation strategies A or C.

3. Students who encounter a big gap, using many adjustments to align their identities and narratives with their experiences, in the first year, applying negotiation strategy B.

4. None of the students in our study encountered a small gap and used many negotiation strategies to align their identities with their experiences. When presenting the analysis we will zoom in on a few students' narratives across their transition process to higher education study programmes in order to provide a thick presentation of the negotiation strategies.

Students who encounter a small gap, using few adjustments to align their identities and narratives with their experiences in the first year (strategies $D$ and E)

In upper secondary school, Filip explained how studying engineering was the only right way for him. He was not yet sure which study programme to choose, but in any event he expected engineering to be problem-based, hands-on and related to the real-life engineering business. His uncle was a professor at the technical university and he had other relatives who were in engineering as well. Asked what kind of academic content he expected he replied that it would be science combined in different ways depending on the study programme, but with a large amount of mathematics no matter what.

Filip belongs to group 2 which consists of students who encountered less of a gap. He had articulated expectations of the academic content he expected even though he was not sure which study programme to choose. In his narrative he drew on the knowledge of engineering gained from his family: 'Of the universities providing science this is the one which is ranked the highest on all those lists, and the one with the biggest budget for its students. Then I have a family who are related to it, an uncle who is professor-different things, which means that it is in the family' (us).

Like other students in this group, Filip had incorporated this knowledge in his narrative and his expectation of what studying would be like. He ended up choosing mechanical engineering, and he was not in any way surprised by the content of the programme. He explained that his motivation for studying was cross-disciplinary:

I have a dream of opening my own business. I am looking forward to working with management. How does one manage craftsmen when building something? I'm interested in the human aspect, too. People don't think engineers work with humans, but I think they just do it in another way than doctors or therapists do. (h1a)

Filip explained that the first part of mechanical engineering is about cars, turbines, windmills and mechanics whereas management would come later: 'It is that part [management] which interests me and the first part is more something I need to go through' (hla). When Filip was interviewed 1 month later, his narrative had completely changed. Now he explains how he primarily wants to focus on energy and secondarily on management — quite the reverse of what he said the month before: 
My tutor (a professor) says don't focus too much on management. It is too arrogant to enter the labour market as a new engineer and say 'I want to be a leader'. Get some more clear-cut engineering skills instead, he said. My intention is to study energy and then combine it with some management later. It is an important challenge for the world to face in the future (...) I also began to see that management is also tough and hard work (...). (h1b)

Filip explains how energy is important to know about in terms of the expanding focus in society on windmills, hybrid cars, etc. There will be a lot of jobs in the energy business too, he explains, where as an energy engineer he will be attractive to employers. He says this business will suit him fine: 'I like the thought of participating in an important area, which can change something in society' (h1b).

Even though Filip's expectations were largely met, he still needed to renegotiate his expectations when his narrative was questioned by his tutor. This represents a turning point from which his narrative is negotiated in terms of what he perceives as being recognised by the institution as legitimate content and perspective, namely a focus on clear-cut engineering skills rather than treating the engineering disciplines as stepping stones towards management.

Filip shifted his perspective on engineering from 'being interested in working with humans like therapists do' (h1a) to 'doing something important for society' (h1b). Furthermore, he made management less attractive, and hence less interesting in his narrative, by noting that it was 'also hard work' (h1b). In that sense, the change in focus presents itself as the result of his reflections of what is attractive.

When Filip was interviewed during his second year, he did not mention management at all and when asked when he became interested in energy he replied:

I've probably been interested for many, many years. When I was a kid I found motors really cool and nuclear power was really awesome. And that's energy business too, so it's really many years ago. (Filip, h2)

By using the words many years Filip emphasises the authenticity in his decision to become an energy engineer. According to narrative psychology this is an example of how Fillip's change of future perspective also affects his narrative retrospect. He may have been interested in motors before, but it was not an important part of his narrative before he entered university. In Filip's narrative a negotiation takes place during the first year when he redefines why he wants to study engineering, what he wants to work with and why. The negotiation runs through a process where he:

1. Recognises that his narrative does not fit into the culture of his new study programme.

2. Makes new sense of what a proper engineering student is.

3. Finds a way to become a proper engineering student which requires him to make new meaning of why he is studying engineering and what he wants to do with it.

4. Eventually gain a sense of belonging.

The example shows how students' choice narratives do not stop when they enter higher education, but are renegotiated as new choices take place. Further, the example shows how Filip performs substantial identity work when bridging the gap between his upper secondary narrative and his experiences. Not only does he shift his focus from management to engineering, but also shifts from issues related to people and to technological and societal issues. 
Even though the gap may appear relatively big from the outside, Filip does not appear to perceive it hard to bridge. He seems to find it easy to transform his narrative and to relate to what he perceives as the requirements of the study programme. What is more, he apparently succeeds in renegotiating his strategy in a few short processes. This is why, in Fig. 1, we categorise Filip's negotiations as type D. The narrative of Elisabeth, that we present in the first part of the findings, is an example of a student who encounters a limited gap and smoothly integrates in both the social and academic parts of the study programme. Therefore, she needs very little adjustment of her narrative and her negotiation strategy is labelled E.

Students who encounter a big gap, using few adjustments to align their identities with their experiences of the first year (strategies $A$ and $C$ )

We continue to explore students who encounter a big gap and their negotiation strategies. This section presents negotiation strategies where students make few adjustments even when facing a big gap when entering higher education. We will present three examples of these strategies.

During his gap year, Christian considers studying computer science. He explains that he is interested in solving computer problems, and that is what he expects to do in computer science: 'We will get to make some solutions for companies. If a company needs some elements to work together, then we can make a project out of it' (g1). When we meet him immediately after the summer holidays he has just entered a software engineering programme. Christian explains that 'to me my study programme is about programming' (h1a). In the interview after he has been studying for a couple of months he says that the only programming assignment he has had so far was too difficult for him to solve, and it seems to him as if everybody has more programming experience than him. Further, programming is only a minor part of the first semester, and Christian struggles with the course in general mathematics, which he finds too hard to relate to his interest in programming. Christian explains how he needs to pull himself together in terms of mathematics, and he is really clear about how he needs to organise his time better. He has not done so yet, he explains, because he is too lazy to keep up the pace. The interview also suggests that his laziness might be related to his lack of interest in the study programme:

Researcher: What do you consider is most interesting academically right now?

Christian: Nothing really... [lowering his voice] uhm no, right now I find it all kind of boring because it is quite uphill at the moment, I do not find anything in particular funny. (h1a)

Christian explains that he expects programming to make a difference to his experiences of studying 'when I begin for real to do programming and I can make some programs myself, then I will consider it just as cool as gaming on the computer and much cooler than watching the television' (h1a). Here, Christian notes that a change in the teaching content could affect his motivation and mentions two rival activities to studying: computer-games and watching television. When interviewed again 2 months later, he is still struggling to find his motivation and keep up in mathematics. He likes the course in programming where he learns different programming languages, but there is little room for actually making programs himself, he says. Instead of doing the assignments in mathematics he has begun making his own projects at home: 
Yesterday I spent my entire evening annoying my friends on their computers by putting in some files to open Internet Explorer at a particular homepage after some time, or deleting their password and their administrator's password from their computer and stuff like that (h1b).

When interviewed for the third time during his first year he is finally taking a course in software engineering, but he finds it extremely boring, partly because he cannot see any use for it. The course is about programming small pieces of larger software programs, but as Christian sees it, "we would never be doing that [the larger program] for a long time. So, it just seems so unreal, so irrelevant' (h1c). The other courses he is taking appear equally pointless: 'I have software engineering, statistics and probability theory, algorithms and then mathematics, and I feel kind of - what's the use for them?' (h1c).

Christian eventually stops attending most of the lectures, and he only hands in the essential assignments, some of which he makes by leaning a lot on fellow students. Instead, he spends all his time, he says, on small projects like penetration testing with a group of friends at his hall of residence and going to social cafés and parties on campus. Actually, he explains, 'penetration testing' means hacking, but it can be used to secure companies, too. In the next vacation he is planning to take a private computer course to learn even more.

What I find cool about penetration testing is that there are always new challenges. If somebody says 'find an entrance' you really have to work for it, new challenges all the time, and you acquire a lot of new knowledge (h1c).

Christian's narrative shows that software engineering does not meet his interest in programming. He finds the programming he learns interesting, but it is not enough to enable him to make his own computer programs. When he finally pursues software engineering as a course, he cannot see the point of it.

All in all, Christian finds it hard to recognise the study programme he imagined in the courses he experiences. Although he passes the exams and hence is formally academically integrated the content of the study fails to capture his interest and motivation and he distances himself from the programme. Instead, he creates a parallel subcultural software engineering programme with the 'penetration-testing projects' as a core activity. Hence, he is not integrated in the official academic community at the university, but is deeply involved in an academic subculture. Through this he is also socially integrated with friends at the residence hall and in the planning of the university's official induction programme for the students who will be joining the university in the following term.

Christian finds a way to keep his narrative of applicable programming as his major interest even though he finds it hard to realise it in his study programme. His negotiation strategy consists of changing his academic focus from formal teaching to the informal learning environment of the hacking community, something that he also sees as being academically relevant for his future career. His adjustment does not concern his interest or perspective, but the context of his involvement. Christian's negotiation strategy is A. He is facing a big gap, but his narrative does not undergo major negotiations; it is merely adjusted a few times in terms of the activities involved and because he satisfies his interests in the parallel community he endures the formal programme as well. This strategy does not appear to conflict with Christian's perception of becoming a 'proper' engineering student, except for his sense of being 'lazy'. Whether in the longer run achieving academic integration in the hacking community instead of in the formal academic community is a viable strategy is an open question. 
Djemal and Emil, who were presented earlier in this paper, are examples of students who also have a negotiation strategy A, but in a different way from Christian. As mentioned previously, Emil finds it hard to recognise the biochemistry he opted for. In an interview at the beginning of his second semester he says that he does not attend the lectures any more but comes into do the exercises, and he does not feel motivated. Furthermore, he has no study group since one of the members left the study and the other has a different lab-schedule from Emil. He finds it easier to study by himself than find a new group. He does not attend any social activities on the study programme either, but prefers spending time with his girlfriend and friends outside campus. He says that as long as he believes things will get better he can endure a period with little or no motivation, and hopes the second year improves. This is what keeps him in the programme:

But if I were to opt out it should be because I found that this was the wrong study I had chosen. Otherwise, I think I could easily choose to say 'well, it will get better'.

As long as I expect... or think it will be better, then I can do it (h1b).

Emil still hopes his study programme will one day meet his expectations and in some of the courses, he occasionally catches a glimpse of that which he considers interesting. At the moment the only thing that Emil highlights in his narrative as being interesting is his book in organic chemistry, and he explains how it is supporting his motivation to keep on studying: 'this is interesting and there are some really great things in that book, and then I think it is great and some day it will be fine' (h1b).

At the beginning of the second year he is still not involved in the social life at university, and he had to do a project alone because everybody else already had a group beforehand through their social network. In spite of his finding more visible relations between theory and practice in the second-year teaching he believes he made a wrong choice and he cannot imagine himself continuing to master's level: 'If I could turn the clock back eighteen months, I would choose the technical university' (h2) and his plan is to move there after completing the bachelor's programme.

Emil has renegotiated his narrative a couple of times during his time at the university. First, he had to change the narrative of being a student from the highly motivated and absorbed Emil to the Emil patiently waiting for the lab work and the teaching to become interesting. Then he had to develop a narrative where the horizon for change was a little more remote, and where the reason for staying was a combination of his idea of the programme still being what he wants to do and of dropping out being a waste of time. In the final interview he has developed a narrative where it is waste of time to leave the study, but he will change to something interesting in the master's programme. This final narrative contains the field of study as being the right one, only in principle (the programme was wrong) and his persistence - that he can stand it, because it would be a waste to quit. The same idea of endurance is present in Djemal's narrative that we presented earlier. Both Djemal and Emil experienced disappointment with the academic content and they did not become socially integrated either.

Emil, Christian and Djemal are examples of students who stay in spite of a big gap between expectations and experiences, with a hope that things will get better. They share this disappointment and do not expect to become academically integrated. While Christian develops an alternative academic integration, however, Djemal and Emil remain isolated. Likewise, Christian is socially integrated in the programme but Djemal and Emil are on the periphery of social life at university. Christian actively integrates into an alternative academic and social community, but the two others merely stand back, give up on integration and hope for things to improve. What the three of them have in common, though, is 
that they succeed in renegotiating their narratives in one or a few processes. This is why we categorise them as applying negotiation strategy A. In total five of the students are categorised as employing this negotiation strategy, making it the one most used by students.

Another strategy where the students only experience a few renegotiations is the one labelled C (Fig. 1). Students experience a smaller gap than the students using strategies A and $\mathrm{B}$, and their strategies are to a large extent similar to that of Filip (strategy D). The students with negotiation strategy $\mathrm{C}$ differ from those with strategy $\mathrm{D}$ in terms of whether they find dealing with the gap problematic or not. Emma (cf. the previous section, p. 22) is an example of a student with negotiation strategy C. She had clear expectations about what to expect, but found it difficult to handle her meeting with first year.

\section{Students who encounter a big gap, using many adjustments to align their identities with their experiences in the first year (strategy $B$ )}

Another group of students encounters a major gap and engage in an almost continuous renegotiation of the narrative of becoming and being a student (negation strategy $B$ in Fig. 1). Emily is one such student.

Since upper secondary school, Emily had been sure that chemical engineering was the right study programme for her, and she visited a technical university to be sure she was about to make the right choice. Nevertheless, a couple of months after starting the programme she is frustrated by what she has experienced:

The first semester is supposed to be hardest. We have assignments and tests all the time, and it is hard to keep track of all the concepts and you also have to get used to the books being in English. And we will soon have an exam and it's a bit stressful with this 'everybody fails this course' all the time. Yeah, great! (h1a)

Both the academic content and the academic culture with its many tests put pressure on Emily. Further she explains how she is confused by most of the courses and the teaching:

He [the teacher] derives some crazy formulas by doing all kinds of exaggerated stuff and you can't recall all the rules in the world and he is really bad at writing down each step and then all of a sudden he is finished. (h1a)

Emily spends all of her time studying, sometimes together with other students, but usually alone since there are no formal study groups. She is frustrated because the content does not always make sense to her, and she finds it difficult to learn by heart in the way she feels she is expected to. She concedes that it can be useful to know things by heart, but she is not happy with the way it is practised in the programme.

In the second interview two months later she is still frustrated by her study experience, in terms of both the content and her own participation. Her interest in engineering is 'that you describe real life, and find out how things work to make them better' (h1b), but so far she has not really experienced that yet. She explains that, 'you need to start at a low level, but uhm well...l I think it will come later' (h1b). Furthermore, she still finds the teaching unsatisfactory and the amount of work exceeds what she can reasonably manage, causing her to feel she does not understand anything at all. Apart from expecting the content she found interesting later, Emily believed that to become more satisfied with her studies she needed to improve ger way of studying and to study even harder than she already did. When asked what she hoped things would be like in the spring she replies that 
I will have everything under control in terms of preparing myself and asking questions in the lectures and using my time more constructively instead of coming home, collapsing, and being stressed, and not just getting it over with. (h1b)

During the autumn semester, Emily kept her thoughts about her difficulties to herself. The first time she articulates them (to someone else than in the interview) is when she talks to a another student about what to do if she fails the first semester exams. The other student says she thinks one needs to get through the first year before being able to make a decision to stay or leave. Thanks to this discussion, Emily realises that she is not the only one facing difficulties, and getting her problems recognised seems to make her believe that it might, after all, be possible after all to get through the programme:

I was so overwhelmed by it being really tough and when you have the feeling of not understanding anything it is hard to find it fun to study. But I would really like to work with this afterwards and now already half a year has passed and it might be possible to get a bachelor's after all. (h1b)

Emily's motivation for becoming an engineer and her interest in chemistry are eventually not enough to keep her on the study programme, as was the case with Emil and Christian. During January she seriously considers to leave the programme because she finds it too hard to cope with the gap between what she expected and her experience of the actual engineering programme, and eventually she does so in February:

I felt myself being stupid in all the courses and I couldn't figure things out. I was not motivated to study and it became too tough and I did not feel that I could keep my self-confidence and self-respect when I felt stupid every day. Then I thought I needed to make a plan about what to do. (h1c)

For quite some time she had doubts about whether to continue studying or not, and in the end she had attended classes without studying for them, and then after a couple of weeks decided to stop. In an interview some 6 months later, she said that it had been a difficult decision because she experienced leaving as a huge defeat and she was emotionally quite affected by the decision.

In Emily's narrative we see how she struggles with negotiating a narrative in which she can keep an understanding of herself as being a 'good student'. Across the interviews during her first year there were both changes and consistency in the way she described and reflected on the first-year experience. On the one hand, she was critical of the teaching and learning experience: she struggled with making meaning of the content and yet she found it met her interests, she found the teaching confusing, and found it difficult to learn by heart which she conceived of as being the expected way of learning. On the other hand, she internalised the problems, relating them to not being clever and hard-working enough, and decided the solution was simply to put in more effort.

During her 6 months on the programme and in the three interviews, the emphasis of her narrative shifted from focusing on the pace and quality of the teaching delivered, to increasingly perceiving herself as someone who did not only have some difficulties to overcome but someone who found it hard to understand the content. Along with her concerns regarding the content and the teaching she was also grappling with social relations to members of her study groups. This gradual change undermines her idea of herself and after she left the programme she said that by the time she had decided to leave ' $I$ just felt that I was the weakest person in the world'. After leaving, Emily worked at a café, and although she expected to continue her education later, she was very unsure which direction 
to pursue. Immediately after leaving the programme, she had expected to return to the technical university. Six months later she was certain that she would not.

Emily was continuously reflecting on and renegotiating her experiences with the programme. In the process she continuously adjusted and changed the interpretation and explanation of her experiences, why her negotiation strategy follows the pattern labelled B.

Another example of a student who experiences a huge gap between his expectations and the reality of higher education is Belal, who studied computer science, and whom we also categorised as having a negotiation strategy B. Belal expected computer science to be ' $a$ lot about coding and then some mathematics alongside' (h1a), but he was surprised to find the opposite. He found it difficult to figure out how to study and how to do the assignments: 'It was like standing in an abyss looking up without being able to get up because you don't really know what you are supposed to do with the assignments' (hla). Belal describes how he 'panicked and did not know what to do' (h1a).

Many components come together in Belal's narrative of how he managed to bridge the gap. He says that at his most frustrated, he attended a presentation organised by the union for computer scientists about job perspectives. He was inspired by one of the presenters who worked in the computer gaming industry: 'I might do something boring right now but when I finish I can go out and do game programming, graphical things or stuff' (h1a), something that 'people' (he did not specify if it was staff or students or both who told him that) at the study programme had told him the computer science programme was not really useful for.

Another turning point in his narrative related to social integration. In the beginning, he did a lot of the assignments by himself at home, and when he met with his study group he felt he was the one with the most difficulties. He felt he needed to do something about it, and therefore changed to a study group who did their assignments together on campus instead of individually at home: 'Sitting together makes it easier to explain and work together to solve it' (h1a). Working in groups also made a difference in terms of being aware of his performance thanks to feedback from the others. Although Belal's parents preferred him to stay at home in the evening, they agreed he could stay on campus to study. He spent most of his time at the university meeting with his study group and getting involved in arranging theatre and movie-nights, etc. He explains that he learned to study properly during the first semester. When the new courses began just before Christmas, Belal used another study strategy, partly because older students had told him that the most important thing was to learn the basics of the course during the first 2 weeks, so the more complicated material later in the course would seem less difficult. Therefore, Belal and his study group prepared themselves carefully before the courses started, finding out what they were supposed to learn, and beginning to study before the course started. It worked: 'When we came to the first week we might just as well have skipped the lectures because we were so much into the stuff' $(h l b)$. During the winter, Belal failed both his courses, however, and when he was interviewed again at the beginning of the second year says he then developed his social life even more and by attending more presentations on 'What to do with a master's in computer science' he felt sure that he still was on the right track: 'I decided to stay even if things went (smiling) well, not so good' (h2). In the summer holiday, Belal decided to work on his lack of programming experience; although it is not a formal or explicit requirement, he finds it to be crucial for attendance on the study programme. Although there are no formal entry requirements of programming experience, he still perceives it to be one of the reasons why he failed: 
When visiting our family abroad, we spent most of the time with them. And they have this thing about resting after lunch and I don't really. So I just sat programming two or three hours a day. (Belal, h2)

Belal found a book with some assignments online, and bought another book and taught himself how to programme in two languages during his holiday.

Throughout Belal's narrative we see how he negotiates bringing together, on the one hand, his own expectations, experiences, and perspectives and, on the other hand, the formal and the implied expectations and requirements of the programme. This negotiation occurred in several steps whereby Belal tried different means and strategies to deal with what he perceived as the causes of his difficulties in order to succeed. These strategies included changing his study habits (staying at the university, trying to read in advance), changing his social integration (changing his study group, involving himself in social activities on campus), defining an end goal that could give meaning to enduring the courses (the prospect of working in the gaming industry), and adjusting his own knowledge base so that it matched the implied rather than the formal requirements (learning how to programme). These strategies were developed and applied during the first year in relation to a number of turning points. These turning points related to the formal academic integration (e.g. failing the courses), the informal academic integration (e.g. being surprised by the amount of mathematics) and the social integration (e.g. finding that the study group was of little help, and that the informal student environment at the department provided a resource for getting through the courses). These turning points also related to changes in the way he perceived himself as a student.

Hence, like Emily he was forced to continuously renegotiate his conception of and interaction with the programme and his issues were similarly related to the content, the teaching and the sense of self. Unlike Emily, however, Belal succeeded in adopting strategies (in relation to both academic and social integration) that meant that his experiences did not develop into a fundamental lack of belief in himself, as he managed to establish an end goal that could compensate for his disappointment with the study contents. What is noteworthy is that the support and ideas for the strategies adopted by Belal came from older students or from somebody outside the programme-not from teachers or the programme curriculum or teaching-learning activities.

The examples of Emily and Belal's narratives show how some students negotiate their narratives when they face a gap and their choice-narratives are challenged by their study programmes. In both cases, we see how these students continuously change their view of what they should do to become a 'proper' student and how they negotiate their identities to become one. Such students experience huge frustrations which is why they ceaselessly try out different strategies to bridge the perceived gap.

\section{Students' negotiation strategies as an analytic approach to institutional departure}

The previous sections have presented an analysis of the narratives of twenty students at different stages in their process of transition from upper secondary school to a science and engineering higher education programme. One result of the analysis is the far from trivial point that all the students to some extent experienced a gap between what they expected and what they experienced when joining the programme. Therefore, it is the rule rather than the exception that the students need to adopt negotiation strategies to cope with the gap. 
A focus of this paper has been the study of how students negotiate their narratives when they experience a gap between their expectations and experiences. We identified five negotiation strategies that differed in terms of the gap, the strategy needed to bridge it and whether the students managed to renegotiate the narrative in a few steps or whether the renegotiation occurred continuously through the first and even second year (cf. Fig. 1). The renegotiation in some cases helped the student to stay on the programme whereas others opted out. These findings raise the question of why some strategies are successful for some students and not for others, and why some students employ one negotiation strategy and other students another. We emphasise that our discussion of these two questions is precisely that - a discussion - rather than a conclusion. Answers to a 'Why?' question in this kind of study can only be tentative, albeit rooted in empirical evidence.

The foci of the negotiation strategies

The findings showed that the experienced gaps were mainly related to the content in the first year, the difficulty of the courses and the teaching and learning methods applied in the programmes. The content-related gap partly had to do with the sequence in the curriculum, frequently a mountain of auxiliary disciplines (typically mathematics) and the content of the programme the students had applied for, only being visible somewhere in the distance. The negotiation strategies applied by the students differed in focus, however.

Some students renegotiated the content of the course-either by changing their perception or interest or by organising supplementary content. Filip (strategy D) succeeded in transforming his interest to something legitimate and hence recognisable by the academic community; from management to energy engineering. Whereas Christian (strategy A) gave up on adjusting his narrative to the expectations of the programme and set up an alternative study programme of hacking. Through this, he avoided having to negotiate the content of the course. Conversely, Djemal (strategy A) persistently tried to meet the expectations of the programme to become a legitimate student of computer science, but did this partly by moving his focus from the programme to what he would have to do after graduation. A parallel between the strategy of Christian and Djemal was that they used other students as facilitators, not teachers or other staff members. All three, however, succeeded in constructing a narrative that could include their interests, their experiences and their expectations.

Other students refrained from renegotiating the content and instead directed their attention and narratives towards the social side of the study programme. Some had adopted that strategy even before university, and others did so after meeting the gap between their expectations and what they found. These students, such as Amalie (strategy D), who did not expect to find interesting content in the educational programme, instead planned to prioritise the social life at the programme. This could be done by for example prioritising study groups, which turned out to be crucial for the survival of some of the students. Even students with strategy B who needed to put some effort into the renegotiation of the narratives could succeed in reconstructing it in a way that made the experience positive, even when it meant accepting that they might have passed the exams but not understood the work.

Emil had renegotiated his narrative as one of deferral, waiting for the bachelor programme to end so that he could change to another programme. He was an example of a student who had adopted an air of resignation (strategy A). This highlights that less negotiation activity is not necessarily a better strategy. So far, the different strategies could 
have foci on the content, social life and postponing the expected. For some students, however, even these strategies were not enough.

The most pronounced example of this was Emily (strategy B) whom we have already presented at some length. She did not settle for learning by heart but wanted to understand the content taught, even though she found it difficult. Through the consecutive interviews ran a continuous negotiation that included her doubts that she was clever enough, that the quality of the teaching was the reason for her difficulties in understanding the content that the subject was right for her and her difficulties in seeing the end goal of the programme. In the final interviews, social disagreements in her study group emerged, too. That she also failed her exams at the end of the first semester was not what made her decide to leave. What eventually made her leave the programme was a fear of losing herself, a feeling which was reinforced when she experienced difficulties understanding the second-semester courses. Staying in the programme would require major negotiations which she did not find it possible to align with her sense of self. All in all, the foci of students like Emily were to construct a consistent narrative that included a sense of meaning in the programme, a sense of perspective in the content and a sense of identity in being a student able to tie these ends together.

Components affecting whether the strategy is successful

Which strategy the students apply does not in itself predict whether a student will opt out or not. Of the students who left their study programme some applied strategies A and some B. None of the students applying strategies C, D or E had left their programmes at the end of the first year, although both Emma (strategy C) and Bastian (strategy E) showed some vulnerability owing to financial and social difficulties. Therefore, it appears that the size of the gap is relevant to students' non-completion, as is whether a large gap at one parameter (e.g. the content being different) could be compensated for by other parameters (e.g. the social life of the programme).

Some of the students who experienced extensive difficulties had a strong determination to get through. One of those, Djemal (strategy A), consciously integrated himself in the social life of the programme, whereas both Belal (strategy B) and Emil (strategy A) remained socially peripheral, although it was difficult to decide whether it was a deliberate strategy or if they would have liked to participate in the social side of the programme. As it turned out in their narratives, they were examples of students who did not seek to become integrated in the programmes. Both of them reconciled themselves to waiting for the study to be over so they could move on to something more interesting.

Why some students applied certain strategies and other students adopted others is a question that cannot be answered in full. The students who experienced a lesser gap had some kind of insight into the study programmes. It was not necessarily detailed knowledge, but a sense of the field based on their parents' backgrounds as graduates in science and engineering or on extracurricular activities. Only one (Elisabeth, strategy E) had acquired detailed knowledge from study counselling or information material, but students whose parents had attended university themselves, where provided with a sense of what university would be like and what they would encounter. This indicates that students' socio-economic background is of importance, because it provides students with a general sense of what studying is like.

Even though the reflections on the students' choices differed markedly between the interviewed students, we could not conclude that students who had based their choice on limited accurate information about the study programmes were less prone to non- 
completion. Likewise, we found no indication that students pursuing university sciences were more or less disappointed or confused or adopted different strategies compared to those pursuing engineering. The study programme did not seem important per se but only in relation to the different students' different expectations.

\section{Tinto's model of institutional departure revisited}

The results of the analyses of the students' narratives are generally in agreement with Tinto's model of student departure (1993). First of all, the focus on time as a key element in student departure is found in both the model and in our analyses. Furthermore, the students' renegotiations when they encountered the university could be considered as a part of their social and academic integration, and the different negotiation strategies depicted in Fig. 1 could be considered as different ways in which students could handle the integration process.

The gaps between the expectations, the experiences and the foci of the renegotiation strategies were in most cases related to the academic system whereas the social system in many cases served as part of the strategy for coping with the gaps. Some students consciously prioritised their social life (both arranged and spontaneous events such as discussion groups, game groups, parties) to increase the probability of staying on the programme, and other students experienced social integration as an important resource for untangling the complexities of the academic system.

With regard to the academic system, the needs for renegotiation were both related to the academic requirements (and, hence, the system accepting the students) and to the gaps in the content of the programme (that is, the students accepting the academic system). Furthermore, difficulties with the academic performance (e.g. passing the exams) interacted with students' experiences of the content.

The interrelation of the different elements in the model has to be emphasised in the light of the present study. Tinto's model indicates interrelations at each stage; however, some of the elements in the renegotiation strategies are not fully captured in the model.

First, the renegotiations in relation to the institutional experiences and the integration were in some cases multifaceted and the students tried different ways of coping with the gap. Second, the academic system should be considered in the plural. Although the programmes had dominant conceptions of proper content, interest and what it was to be a student, some of the students related to different academic communities, some of which were informal subcultures. It seems that one viable way of dealing with the gap is to relate to an academic subculture, which is not visible in Tinto's model. Third, the issue of identity is absent or strongly downplayed in the model. Some of the students in this study experienced that the study programme had a damaging effect on their identity and in the end they had to leave in order to preserve their sense of identity. Academic and social integration means more than finding a way into the discipline. It means renegotiating identity in a way that is both sensible and legitimate for the student her/himself and for (one of the cultures of) the study programme.

As we commented previously in this article, we do not consider the issue of identity as incompatible with Tinto's model but the analysis of the different renegotiation strategies in relation to the students' narratives and the importance of identity emphasise that this is indeed a highly important element, albeit not highlighted in the model.

A revision of the model would, in the light of our study, emphasise the presence of more than one academic system, the question of identity and the dynamic nature of the renegotiations, which do not simply occur through a number of stages but go back and forth. 
This could also make it more sensitive to the difficulties of students with a social, cultural, ethnic or economic background that makes the integration process more laborious.

\section{What did we learn from studying students' journeys into higher education?}

In the present study we have shown that students arrive at university with expectations about what they will find and what they will experience, and that virtually all students experience a gap between their expectations and their experiences. The gap can relate to the content of the programme, to the academic requirement, to the teaching and learning activities, but also (albeit less common in our data) to the social environment or to financial requirements. The students apply strategies for renegotiating their narratives of why they are in the programme, what kind of students they are, what the programme is like, etc., in order to construct a narrative that can include both their experiences and their identity.

Some students succeed in constructing a narrative through which they change their own focus of interest, whereas others defer from expecting the study to be interesting until later or even at all. In that case, they can focus their narrative on social integration in the programme or they can refrain from expecting to become integrated at all.

The renegotiation involves several elements of student life (both academic and social) and consequently it is a complex endeavour. For some students it is a continuous process through at least the first year of study through which they strive to make sense of what they meet. That being so, it is also a vulnerable process whereby students, even if they join the programme, determined to complete it, experience difficulties in constructing a viable narrative and therefore often need to consider leaving the course.

\section{References}

Adelman, C. (2006). The toolbox revisited: Paths to degree completion from high school through college. Washington: U.S. Department of Education.

Andrews, M., Squire, C., \& Tamboukou, M. (2008). Doing narrative research. London: Sage publications.

Ball, S. J., Maguire, M., \& Macrae, S. (2000). Choices, pathways and transitions post-16: New youth, new economies in the global city. London: RoutledgeFalmer.

Bergerson, A. A. (2009). Special issue: College choice and access to college: Moving policy, research, and practice to the 21st century. ASHE Higher Education Report, 35(4), 1-141.

Braun, V., \& Clarke, V. (2006). Using thematic analysis in psychology. Qualitative Research in Psychology, $3(2), 77-101$.

Bruner, J. (1990). Acts of meaning. Harvard: Harvard University Press.

Bruner, J. (2004). Life as narrative. Social Research, 71, 691-710.

Colley, H. (2010). Time in learning transitions through the lifecourse: A feminist perspective. In K. Ecclestone, G. Biesta, \& M. Hughes (Eds.), Transitions and learning through the lifecourse. London: Routledge.

Ecclestone, K., Biesta, G., \& Hughes, M. (Eds.). (2010). Transitions and learning through the life course. London: Routledge.

EU. (1999). The Bologna declaration of 19 June 1999. Bologna: The European Higher Education area.

Flyvbjerg, B. (2011). Case study. In N. K. Denzin \& Y. S. Lincoln (Eds.), The Sage handbook of qualitative research (4th ed., pp. 301-316). Thousand Oaks, California: Sage.

Goldrick-Rab, S., Carter, D. F., \& Wagner, R. W. (2007). What higher education has to say about the transition to college. Teachers College Record, 109, 2444-2481.

Hasse, C. (2002). Kultur i bevagelse - fra deltagerobservation til kulturanalyse - $i$ det fysiske rum. Frederiksberg: Samfundslitteratur.

Hasse, C. (2008). Learning and transition in a culture of playfull physicists. European Journal of Psychology of Education, 23(2), 149-165. 
Henriksen, E. K., Dillon, J., \& Ryder, J. (2013). Recruitment, retention and gender equity in science, technology, engineering and mathematics higher education (working title). London: Springer.

Holland, D., Lachicotte, J. W., Skinner, D., \& Cain, C. (1998). Identity and agency in cultural worlds. Cambridge, Massachusetts: Harvard University Press.

Holmegaard, H. T. (2013). Students' narratives, negotiations, and choices. A longitudinal study of Danish students' transition process into higher education science, engineering and mathematics. (Vol. Doctoral Dissertation). Copenhagen: Department of Science Education, University of Copenhagen.

Holmegaard, H. T., Madsen, L. M., \& Ulriksen, L. (2012). To Choose or Not to Choose Science: Constructions of desirable identities among young people considering a STEM higher education programme. International Journal of Science Education, 1-30. doi: 10.1080/09500693.2012.749362.

Holmegaard, H. T., Ulriksen, L. M., \& Madsen, L. M. (2012). The Process of choosing what to study: A longitudinal study of upper secondary students' identity work when choosing higher education. Scandinavian Journal of Educational Research, 1-20. doi: 10.1080/00313831.2012.696212.

Illeris, K., Katznelson, N., Simonsen, B., \& Ulriksen, L. (2002). Ungdom, identitet og uddannelse. Frederiksberg: Center for Ungdomsforskning, Roskilde Universitetsforlag.

Johannsen, B., Rump, C., \& Linder, C. (2013). Penetrating a wall of introspection: A critical attrition analysis. Cultural Studies of Science Education, 8, 87-115. doi:10.1007/s11422-012-9436-9.

Kvale, S. (1996). InterViews: An introduction to qualitative research interviewing. Thousand Oaks, California: Sage Publications.

Kvale, S. (2006). Dominance through interviews and dialogues. Qualitative Inquiry, 12(3), 480-500.

McAdams, D. P., Josselson, R., \& Lieblich, A. (Eds.). (2001). Turns in the road. Washington DC: American Psychological Association.

Polkinghorne, D. E. (1988). Narrative knowing and the human sciences. Albany: State University of New York Press.

Roth, W.-M., \& Tobin, K. (Eds.). (2007). Science, learning, identity. Sociocultural and cultural-historical perspectives (Vol. 7). Rotterdam/Taipei: Sense Publishers.

Scott, P. (1995). The meanings of mass higher education. London: Open University Press.

Søndergaard, D. M. (1996). Tegnet på kroppen. Køn: Koder og konstruktion blandt unge voksne i Akademia. København: Museum Tusculanum Press.

Terenzini, P. T., Cabrera, A. F., \& Bernal, E. M. (2001). Swimming against the tide: The poor in American Higher education. New York: College Entrance Eximination Board.

The Danish Ministry of Children and Education. (2011). Studenternes fagvalg 2005-2011.. Statistik og analyseKøbenhavn: UNI-C.

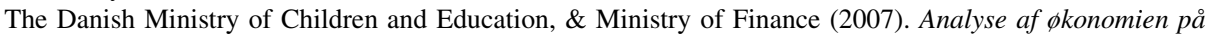
hhx- og htx-uddannelserne og sammenligning af фkonomiske vilkår på de gymnasiale uddannelser. København.

The Danish Ministry of Children and Education, U.-C. (2010). Studenternes fagvalg 2005-2009. Statistik og analyseKøbenhavn.

Tierney, W. G. (1999). Models of minority college-going and retention: Cultural integrity versus cultural suicide. Journal of Negro Education, 68(1), 80-91.

Tinto, V. (1993). Leaving college. Rethinking the causes and cures of student attrition (2nd ed.). Chicago, London: The University of Chicago Press.

Tonso, K. L. (2006). Student engineers and engineer identity: Campus engineer identities as figured world. Cultural Studies of Science Education, 1, 273-307.

Ulriksen, L., Madsen, L. M., \& Holmegaard, H. T. (2010). What do we know about explanations for drop out/opt out among young people from STM higher education program? Studies in Science Education, 46(2), 209-244.

Ulriksen, L., Murning, S., \& Ebbensgaard, A. B. (2009). Når Gymnasiet er en fremmed verden. Frederiksberg: Samfunds litteratur.

Wertsch, J. V. (1993). Voices of the Mind. A sociocultural approach to mediated action. Cambridge, Massachusetts: Harvard University Press.

Yorke, M., \& Longden, B. (2004). Retention and student success in higher education. Maidenhead, UK: Open University Press.

\section{Author Biographies}

Dr. Henriette Tolstrup Holmegaard is a postdoctoral researcher at the Department of Science Education, University of Copenhagen, Denmark. She holds a Ph.D in Science Education. Her Dissertation is a longitudinal study of upper secondary school students' transition-process into higher education STEM study 
programmes. Together with the co-authors of this paper she has published on students' choices of higher education in general and in particular on why students' do not choose a future within STEM. In the near future she plans to carry out research on STEM-students' choice of master-theses and their transition into first employment.

Dr. Lene Møller Madsen is an Associate Professor in science education at the Department of Science Education, University of Copenhagen. She holds a Ph.D. in geography and has published on the development of spatial thinking skills, students' meeting with teaching in geography and how institutional cultures interact with researchers' perceptions of fieldwork. Together with the co-authors in this paper she has been part of the European project IRIS (Interests and Recruitment in Science) supported by the EU Seventh framework programme (FP7). She is interested in the academic integration of students, retention and gender issues.

Dr. Lars Ulriksen is an Associate Professor in higher education teaching and learning at the Department of Science Education, University of Copenhagen, Denmark. He has been leading the Danish part of the European project IRIS (Interests and Recruitment in Science) supported by the EU Seventh framework programme (FP7) (book in preparation). His research areas include the meeting of higher-education students with the culture and curriculum of the programmes. He has developed the notion of the implied student and together with the co-authors of this paper published on student retention, transition and educational choices. 